\begin{tabular}{l|c|c|}
\hline & International Journal of Current Research in \\
Biosciences and Plant Biology \\
\hline EXCELLENT \\
PUBLISHERS
\end{tabular}

\title{
Effect of Malted Cereals on the Sugar Content of Sorghum Gruel
}

\author{
P.S. Awodi*, A. B. Ella, G. B. Asaar and T. J. Tivkaa \\ Department of Science Laboratory Technology, Benue State Polytechnic, Ugbokolo, Nigeria \\ *Corresponding author.
}

\begin{tabular}{|c|c|}
\hline Article Info & ABSTRACT \\
\hline Date of Acceptance: & \multirow{8}{*}{$\begin{array}{l}\text { Gruel is an unfermented non-alcoholic beverage produced from sorghum grains. } \\
\text { Malted cereals (rice, sorghum and maize) were separately used to liquefy sorghum } \\
\text { gruel produced under the same conditions. The sugar content of the three samples of } \\
\text { sorghum gruel and the sugar content of the hydrolysate of raw sorghum mash } \\
\text { hydrolyzed by the malted cereals were assessed. In vitro digestibility of the gruel } \\
\text { samples as well as the organoleptic qualities of the gruel samples were evaluated. The } \\
\text { results of the sugar analysis of the gruel samples are; } 1.31,1.07 \text { and } 1.03(\mathrm{mg} / \mathrm{mL}) \text { for } \\
\text { the gruel liquefied by malted rice, malted sorghum and malted maize respectively. The } \\
\text { gruel starch digestion rate was fastest in the gruel liquefied by malted sorghum at one } \\
\text { hour followed by the gruel sample liquefied by malted rice and then gruel liquefied by } \\
\text { malted maize. The results of the organoleptic qualities showed that the gruel liquefied } \\
\text { by malted rice did not differ significantly ( } P>0.05) \text { in taste from gruel liquefied by } \\
\text { malted sorghum, but there is significant difference }(P<0.05) \text { between gruel liquefied } \\
\text { by malted maize and the gruel liquefied by malted rice. Due to the rising cost of sugar } \\
\text { and its effect on diabetic patients, we conclude that the application of malted cereals, } \\
\text { especially malted rice, in gruel production is not only economical, but value for those } \\
\text { seeking for low sugar diet. }\end{array}$} \\
\hline & \\
\hline $\begin{array}{l}\text { Date of Publication: } \\
\text { 06 July } 2018\end{array}$ & \\
\hline Keywords & \\
\hline & \\
\hline Hydrolysate & \\
\hline & \\
\hline Malt & \\
\hline
\end{tabular}

\section{Introduction}

Sorghum has been known as a credible raw material for production of value-added products like beer (Skinner, 1976; Owuama, 1999; Owuama et al., 2011), burukutu (Orji and Uvere, 200; Kingsley and Victor, 2007) and complementary foods (Onwurafor et al., 2017). Sorghum is also used for production of non-alcoholic beverages like gruel, a traditional nonalcoholic beverage with a limited shelf life.
The consumption of gruel is now on the increase, partly due to the need to reduce sugar intake as part of the battle against diabetes. Many people are looking unto gruel as a potential substitute to the sugar sweetened soft drinks, therefore, during ceremonies such as marriages, naming ceremonies, funerals and other social gatherings, gruel is served. Similar non alcoholic beverage called "kunu" is produced in the core Northern States of Nigeria from other raw materials like tiger nut, ground nut 
and rice, hence such beverages (kunu) beer the name of the substrate from which it is being produced, such as "kunun aya" (tiger nuts gruel), "kunun geda" (ground nut's gruel) and "kunun chinkafa" (rice gruel). In the middle belt states (Benue and Kogi) of Nigeria, gruel is usually produced from sorghum grains. Malted cereals like malted maize and malted sorghum or tubers like dried sweet potatoes (potato chips) and Gladiolus actinomorphanthus are often added to sorghum wort in order to hydrolyze the starch present in the gruel thereby liquefying the beverage. The hydrolytic enzyme in the malted cereal aids in digesting the thick wort thereby converting the complex carbohydrates in the cereal to simple sugars (Deware et al., 1997). The main objective of malting cereals is to promote synthesis of hydrolytic enzymes which will solubilize large macro molecules into low molecular weight compounds (Mohammed and Emmanuel, 2014). Several types of cereals have been used for malting for different purposes. The malting potentials of different cereals have been studied (Malleshi and Desikachar, 1986). Malts from wheat, sorghum and maize have been studied with respect to their use in food formulation. Malting of barley is a recognized process associated with beer production. The conversion of barley into beer represents mankind's oldest and most complex example of applied enzymology (Mohammed and Emmanuel, 2014).

In recent times, malted rice is used as a source of starch hydrolyzing enzyme to liquefy gruel. The sale of different malted cereals in the market has posed a problem in the choice of malted cereal to be used for gruel production, therefore, this present study is aimed at the determination of the effect of malted cereals on the sugar content of sorghum gruel.

\section{Materials and methods}

\section{Materials}

The sorghum grains used for the production of gruel was bought from market in Otukpo, while the malted cereals (sorghum, maize and rice) were bought from market in Ugbokolo, Okpokwu Local Government Area in Benue State, Nigeria.

\section{Methods}

Production of gruel from sorghum: $5 \mathrm{~kg}$ of cleaned and washed sorghum grains were steeped in clean bottled water for 24 hours. Thereafter, the steeped sorghum grains were wet milled in a clean commercial grinding engine. The resultant sorghum slurry was mashed with clean bottled water. Boiling water was added to the sorghum slurry in an unequal ratio of $(3: 1) \mathrm{v} / \mathrm{v}$, and stirred to form a homogenous solution. The malted cereal which was previously ground and mashed with clean bottled water was added to the cooked sorghum wort. The cooked wort was kept to be hydrolyzed by the malted cereal at room temperature for 12 hours. Thereafter the gruel was sieved with a clean filter, at this point, the gruel is ready for consumption. For the purpose of this research, three sorghum gruel samples liquefied by three different malted cereals (malted rice, malted maize and malted sorghum) were produced under the same conditions.

\section{Determination of sugar content of unmalted and malted cereal samples (rice, maize and sorghum): $5 \mathrm{~g}$ of unmalted rice which was previously ground in a clean laboratory morta was dispensed into $250 \mathrm{~mL}$ flat bottom conical flask, $100 \mathrm{~mL}$ of distilled water was added and stirred, the solution was filtered with Whatman filter paper (size: $125 \mathrm{~mm}$ ). The filtrate was used for sugar determination by dinitrosalicyclic acid method (Miller, 1959; Dashen et al., 2011). This experiment was repeated with unmalted maize and unmalted sorghum. Similarly, $5 \mathrm{~g}$ of specific malted cereal (rice, sorghum, maize) was treated as described above for their sugar content determination.}

Hydrolysis of sorghum mash with the malted cereals (malted rice, malted maize and malted sorghum): $100 \mathrm{~mL}$ of distilled water was added to $10 \mathrm{~g}$ of sorghum flour in a $250 \mathrm{~mL}$ conical flask, 5 $\mathrm{g}$ of ground malted rice was added and stirred to form a homogenous solution. As hydrolysis of the 
sorghum mash proceeds, $5 \mathrm{~mL}$ of the hydrolate was withdrawn from the flask at $0 \mathrm{hr}$ and 60 mins. Each aliquot $(5 \mathrm{~mL})$ of the hydrolysate was filtered with whatman filter paper (size: $125 \mathrm{~mm}$ ). The filtrate of each sample was used for reducing sugar determination by dinitrosalicylic acid method (Miller, 1959; Dashen et al., 2011).

Hydrolysis of sorghum mash with malted maize and malted sorghum was also separately carried out. The hydrolysate of each malted cereal and sorghum slurry was used for sugar determination as mentioned earlier.

Physicochemical properties of gruel samples: The temperature, $\mathrm{pH}$ and reducing sugar content of each gruel sample (i.e. sorghum gruel liquefied by malted rice, sorghum gruel liquefied by malted maize and sorghum gruel liquefied by malted sorghum), were evaluated. Temperature of each gruel sample was determined by inserting a digital thermometer (mextech multi thermometer model, china) into the gruel sample. $\mathrm{pH}$ was measured with a digital pH meter (Model 96107, Hanna instruments, China) after standardization with $\mathrm{pH} 3$ and 7 buffers (BDH, England). The sugar content of each gruel was assessed by 3- 5- dinitrosalicylic acid method (Miller, 1959; Dashen et al., 2011).

In vitro digestibility test on gruel samples: 1.0 $\mathrm{mL}$ of gruel sample (sorghum gruel prepared with malted rice) was mixed with $3 \mathrm{~mL}$ of pooled human saliva, $5 \mathrm{~mL}$ of distilled water was added and incubated in a dialysis bag. The dialysis bag was suspended in a beaker containing $200 \mathrm{~mL}$ of distilled water. The beaker was maintained at $37^{\circ} \mathrm{c}$ in a water bath. $1 \mathrm{~mL}$ of the dialysate was removed every hour for 3 hours and analysed for reducing sugar by 3- 5- dinitrosalicylic acid method. The in vitro digestibility test was also carried out on sorghum gruel prepared with malted maize and sorghum gruel prepared with malted sorghum. The dialysate of each sorghum gruel was evaluated by dinitrosalicylic acid method.

Sensory evaluation: The sensory characters (colour, consistency, aroma, taste mouthfeel and overall acceptability) of the gruel samples liquefied by the malted cereals (rice sorghum and maize) were assessed by a 10- member panel, using a 5 point scale. Where: $5=$ like very much; 4 =like; $3=$ neither like nor dislike; 2 = dislike; $1=$ dislike very much. A cut - off point of 3.0 was established as the reference based on the procedure described by Wokoma and Aziagba (2001) and Adekalu et al. (2016).

\section{Statistical analysis}

The data obtained were subjected to descriptive analyses. Analysis of variance (ANOVA) were performed by SPSS, version 21 statistical package.

\section{Results and discussion}

Malting of the cereals (rice, sorghum and maize) resulted in increases in their sugar content from $0.35,0.39$ and $0.40(\mathrm{mg} / \mathrm{ml})$ to $1.7,0.6$ and 1.74 $(\mathrm{mg} / \mathrm{ml})$ respectively (Table 1$)$. Malted rice yielded more sugar than malted sorghum and malted maize. This result agrees with Mahammed and Emmanuel (2014)'s report that malting of rice increased the quantity of hydrolytic enzymes present in them. The enzyme that was produced during malting lead to the hydrolysis of starch in the grain resulting in the release of sugar. It has been shown that a significant positive correlation exists between amylase activity and reducing sugar (Etokakpan and Palmer (1990).

Mashing of sorghum flour with malted rice as shown in Table 2 yielded more sugar $(1.91 \mathrm{mg} / \mathrm{ml})$ compared with $(1.90 \mathrm{mg} / \mathrm{ml})$ from using malted sorghum and $(1.48 \mathrm{mg} / \mathrm{ml})$ from malted maize. The hydrolysis of raw sorghum flour with malted rice, sorghum and maize (Table 2) for one hour resulted in 3,2 and $1 \%$ increases in their sugar contents respectively.

The physicochemical properties of the gruel samples as presented in Table 3 shows that sorghum gruel liquefied by malted rice yielded 
more sugar $(1.31 \mathrm{mg} / \mathrm{ml})$ than the gruel liquefied by malted sorghum $(1.07 \mathrm{mg} / \mathrm{ml})$ and malted maize $(1.03 \mathrm{mg} / \mathrm{ml}) \mathrm{A}$ similar trend was observed in the $\mathrm{pH}$ of the gruel samples. Akoma et al. (2002) suggested that the higher sugar content in the gruel liquefied by malted rice may be responsible for the higher acidity. Since digestion of starch begins in the mouth, in vitro digestibility of the gruel samples were evaluated (Fig. 1). The rate at which salivary amylase digested the gruel liquefied by malted sorghum was faster than in the gruel liquefied by malted rice and malted maize.

Table 1. Unmalted and malted cereals sugar content.

\begin{tabular}{lll}
\hline \multirow{2}{*}{ Cereals $(\mathbf{g})$} & Reducing sugar $(\mathbf{m g} / \mathbf{m L})$ & \\
\cline { 2 - 3 } & Unmalted & Malted \\
\hline Sorghum grain & 0.35 & 1.7 \\
Maize grain & 0.39 & 0.6 \\
Rice grain & 0.14 & 1.74 \\
\hline
\end{tabular}

Table 2. Hydrolysis of sorghum mash with malted cereals.

\begin{tabular}{lll}
\hline \multirow{2}{*}{ Sorghum mash hydrolyzed by: } & Reducing sugar $(\mathbf{m g} / \mathbf{m L})$ \\
\cline { 2 - 3 } & $\mathbf{0}$ hour & $\mathbf{1}$ hour \\
\hline Malted rice & 1.86 & 1.91 \\
Malted sorghum & 1.87 & 1.88 \\
Malted maize & 1.46 & 1.86 \\
Water (control) & 0.61 & 0.85 \\
\hline
\end{tabular}

Table 3. Physicochemical properties of sorghum gruel liquefied by malted cereals.

\begin{tabular}{llll}
\hline Gruel liquefied by & Temp & pH & Sugar $(\mathbf{m g} / \mathbf{m L})$ \\
\hline Malted rice & 29.3 & 4.7 & 1.31 \\
Malted sorghum & 28.8 & 4.9 & 1.07 \\
Malted maize & 28.3 & 5.4 & 1.03 \\
\hline
\end{tabular}

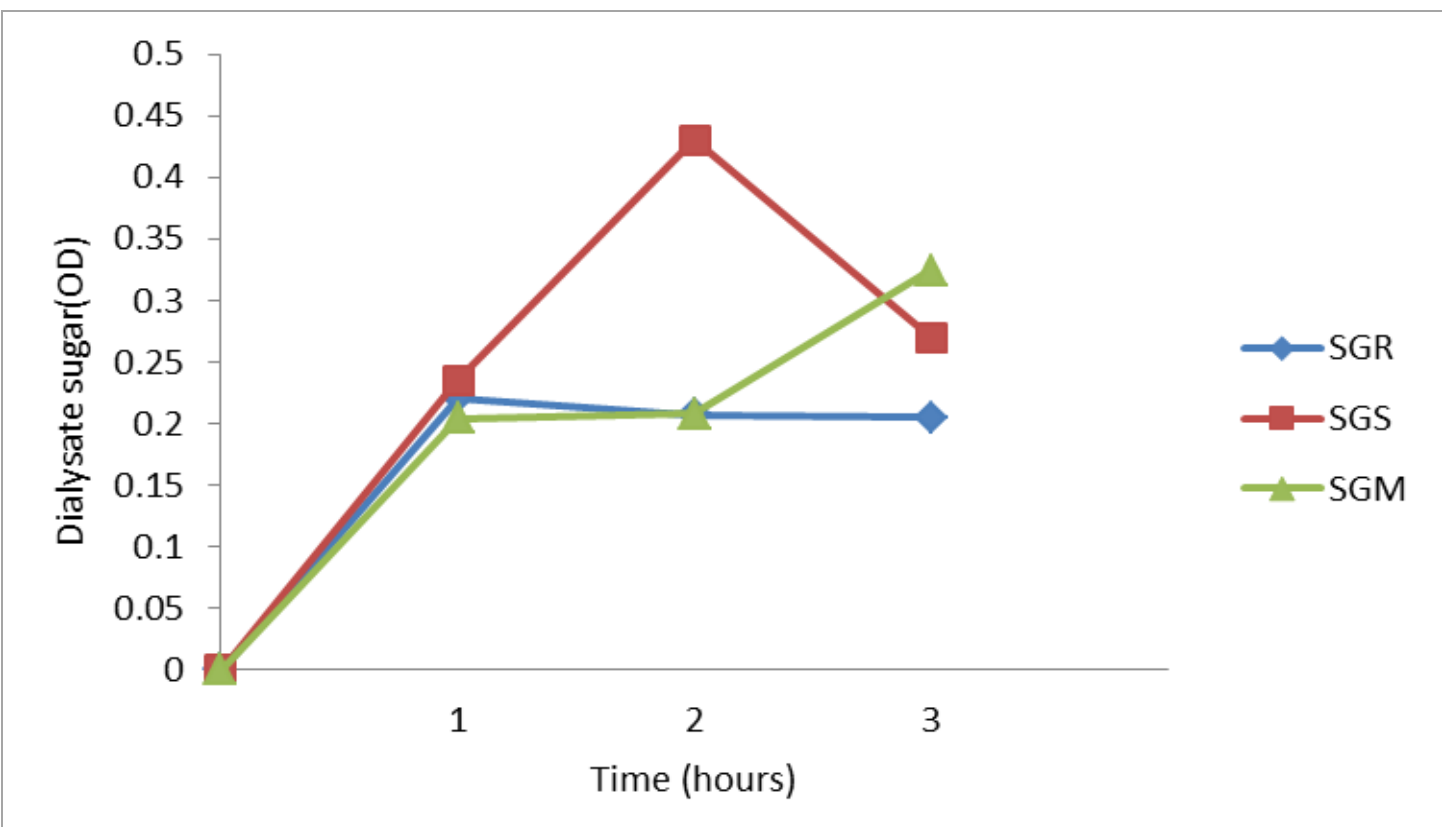

Fig. 1: In vitro digestibility test on gruel samples. SGR= Sorghum gruel liquefied by malted rice. SGS = Sorghum gruel liquefied by malted sorghum. SGM = Sorghum gruel liquefied by malted maize. 
Table 4. Sensory quality characters of sorghum gruel liquefied by malted cereals.

\begin{tabular}{lllllll}
\hline \multirow{2}{*}{ Gruel liquefied by: } & \multicolumn{2}{l}{ Sensory scores } & & & \\
\cline { 2 - 7 } & Colour & Consistency & Aroma & Taste & Mouth feel & Overall acceptability \\
\hline Malted rice & 3.20 & 3.13 & 3.13 & 3.10 & 3.10 & 3.13 \\
Malted sorghum & 3.33 & 2.90 & 3.03 & 3.00 & 2.67 & 3.01 \\
Malted maize & 3.13 & 2.67 & 2.60 & 2.40 & 2.60 & 2.75 \\
\hline
\end{tabular}

The result of the organoleptic qualities shows that the gruel liquefied by malted rice did not differ significantly $(P>0.05)$ from the gruel liquefied by malted sorghum in taste, but there is significant difference $(P<0.05)$ between the gruel liquefied by malted maize and malted rice (Table 4). The higher level of enzyme activity in malted rice and sorghum (Table 1) which resulted in efficient conversion of sorghum starch into glucose has enhanced the taste of the gruel liquefied by them, hence their overall acceptability was above the cut-off point. Sorghum gruel liquefied by malted maize was not accepted, which may be attributed to the low reducing sugar content (enzyme activity) in malted maize as seen in Table 1.

\section{Conclusion}

The results of this research have shown that the three malted cereals (rice, sorghum and maize) can be used in the production of sorghum gruel. However, for people with impaired carbohydrate metabolism, malted maize may be better in production of gruel for them. Due to the rising cost of sugar and its effects on diabetic patients, we conclude that the application of malted rice and sorghum in gruel production is economical.

\section{Conflict of interest statement}

Authors declare that they have no conflict of interest.

\section{References}

Adekalu, O. A., Atanda, S.A., Borisade, T. J., Adeniran, T. R., 2016. Physicochemical, microbial and organoleptic evaluation of scalded Lycopersicon esculentum stored in brine and natural spice extracts. Niger. J.
Microbiol. 30(1), 3339-3344.

Dashen, M.M., Ado, S.A., Ameh, J.B., Mawak, J.D., 2011. Effect of sugar supplementation on citric acid production from orange pulp by Aspergillus niger using submerged fermentation. Niger. J. Microbiol. 25, 23972402.

Dewar, J., Taylor, J.R.N., Berjak, P., 1997. Determination of improved steeping conditions for sorghum malting. J. Cereal Sci. 26, 129-136. Etokakpan, O.U., Palmer, G.H., 1990. A simple diamylase procedure for the estimation of alpha and beta amylases. J. Inst. Brewing. 96, 89-91.

Jenkin, D.J.A., Wolever, T.M.S., Buckley, G., 1988. Low glycemic-index starchy foods in the diabetic diet. Am. J. Clin. Nutr. 48, 248-254.

Kingsley, C. E., Victor, E. E., 2007. A Kinetic study of burukutu fermentation. J. Engg. Appl. Sci. 2(7), 1193-1198.

Malleshi, G., Desikachar, M.S.R., 1989. Studies on the comparative malting characteristics of some tropical cereals and millets. J. Inst. Brew. 92, 174-176.

Miller, G.L., 1959. Use of dinitrosalicylic acid reagent for determination of reducing sugar. Anal. Chem. 3, 426-428.

Mohammed, A. M., Emmanuel, O. A., 2014. Hydrolytic enzyme levels in malted cereals. Adv. Biochem. 2(5), 76-79.

Onwurafor, E. U., Umego, E. C., Uzodinma, E. O., Samuel, E. D., 2017. Chemical, functional, pasting and sensory properties of sorghummaize-mungbean malt complementary food. Pak. J. Nutr. 16(11), 826-834.

Orji, F.S., Uvere, P.O., 2002. Lipase activity during malting and fermentation of sorghum for burukutu production. J. Inst. Brew. 108(2), 256260.

Owuama, C. I., 1999. Brewing beer with sorghum. J. Inst. Brew. 105, 23-34. 
Owuama, C. I., Chiangi, J. S., Adeyemo, M. O., 2011. Effect of Discorea cayensis and Ipomea batatas extracts on sugar content of sorghum mash. Niger. J. Microbiol. 25, 2437-2444.

Skinner, R., 1976. Tropical larger beer brewing with sorghum malt. Brew. Malt. Int. 6, 26-27.
Wokoma, E. C., Aziagba, G. C., 2001. Sensory evaluation of dawadawa produced by traditional fermentation of African yam bean (Sphenostylis stenocarpa Hams.) seeds. J. Appl. Sci. Environ. Manag. 5(1), $85-91$.

\section{How to cite this article:}

Awodi, P.S., Ella, A.B., Asaar, G.B., Tivkaa, T.J., 2018. Effect of malted cereals on the sugar content of sorghum gruel. Int. J. Curr. Res. Biosci. Plant Biol. 5(7), 43-48.

doi: https://doi.org/10.20546/ijcrbp.2018.507.006 